\title{
PENGARUH BERBAGI PENGETAHUAN PERENCANAAN KARIR TERHADAP EFIKASI DIRI DALAM MEMBUAT KEPUTUSAN KARIR
}

\section{EFFECT OF KNOWLEDGE SHARING IN CAREER PLANNING TO CAREER DECISION- MAKING SELF-EFFICACY}

\author{
Eko Imam Santosa \\ Fathul Himam \\ Fakultas Psikologi Universitas Gadjah Mada Yogyakarta \\ Email: e.imamsantosa@gmail.com,fathulhimam@yahoo.com
}

\begin{abstract}
The purpose of this experimental study was to determine the effectiveness of knowledge sharing in career planning to increase career decision making self-efficacy of job seekers. Subjects were 57 people subject, 30 subjects were in the experimental group and 27 were in the control group. The criteria of subjects were bachelor with 0 to 3 years experiences who has a low, medium or high CDSE score. The experimental group will receive manipulation, either group was a waiting list for the next batch and data was not analized. Data analysis was performed using mixed anova. The results of data analysis showed that career planning using knowledge sharing methods was statistically proven to improve career decision making self-efficacy of job seekers $(F=22.736, p<0.00)$. Findings and suggestions for other researchers are discussed further.
\end{abstract}

Keywords: knowledge sharing, career planning, career decision

\begin{abstract}
ABSTRAK
Tujuan utama dari penelitian eksperimen ini adalah untuk mengetahui efektivitas berbagi pengetahuan dalam perencanaan karir terhadap peningkatan efikasi diri para pencari kerja dalam membuat keputusan karir. Subjek penelitian adalah 57 orang subjek dengan 30 subjek di kelompok eksperimen dan 27 orang di kelompok kontrol. Kriteria subjek adalah sarjana dengan rentang kelulusan 0 hingga 3 tahun yang memiliki skor CDSE rendah, sedang dan tinggi. Kelompok eksperimen akan mendapat manipulasi sedang kelompok kontrol menjadi waiting list setelah penelitian selesai. Analisis data dilakukan dengan menggunakan anava campuran. Hasil analisis data menunjukkan bahwa perencanaan karir dengan menggunakan metode berbagi pengetahuan terbukti secara efektif mampu meningkatkan efikasi diri dalam membuat keputusan karir para pencari kerja $(F=22,736 ; p<0,00)$ dengan sumbangan efektif sebesar $38,8 \%$. Temuan penelitian dan saran bagi peneliti lain didiskusikan lebih lanjut.
\end{abstract}

Kata kunci : berbagi pengetahuan, perencanaan karir, keputusan karir

Pengangguran masih menjadi masalah yang belum dapat dipecahkan di Indonesia. Setidaknya hal itu dapat dilihat dari data Badan Pusat Statistik Indonesia (BPS) per Agustus 2011. Data menun- jukkan terdapat 7.700.086 pengangguran terbuka yang terdiri atas orang-orang yang sedang mencari pekerjaan, mempersiapkan usaha, merasa tidak mungkin mendapatkan pekerjaan maupun sudah punya 
pekerjaan tetapi belum mulai bekerja. Berdasarkan angka total tersebut terdapat pengangguran terbuka yang berasal dari para sarjana sejumlah 492.343 dan dari diploma (I/II/III/Akademi) tercatat 244.687 pengangguran terbuka.

Data di atas menunjukkan kenyataan bahwa saat ini lapangan pekerjaan yang ada masih belum dapat menyerap para pencari kerja khususnya yang berasal dari lulusan universitas $(9,57 \%$ dari total pengangguran terbuka di Indonesia). Penelitian Suryadarma, Suryahadi dan Sumarto (2007) memberi gambaran fenomena yang menarik. Hasil penelitiannya menunjukkan bahwa mayoritas pengangguran terdidik berasal dari angkatan muda yang belum memiliki pengalaman, yang tinggal bersama orang tuanya. Lebih dari itu, menurut Greenbank dan Hepworth (2008b), tingginya angka pengangguran sebagai salah satu indikator lemahnya perencanaan karir lulusan dari universitasuniversitas baik diploma maupun sarjana.

Pada penelitian sebelumnya, Mulyana (2009) melakukan wawancara preliminary terhadap lima orang sarjana baru dan karyawan yang baru memasuki dunia kerja dalam suatu perusahaan atau organisasi dengan latar belakang pendidikan dan profesi yang berbeda. Hasil wawancara menunjukkan bahwa individuindividu tersebut mengalami permasalahan-permasalahan karir yang dimulai dari pencarian awal karir sampai ketika individu tersebut memasuki suatu organisasi atau perusahaan. Beberapa di antaranya adalah kesulitan dalam mendapatkan karir pilihan, ketidaksesuaian pekerjaan yang dijalani dengan latar belakang pendidikan, minat dan keahlian. Banyaknya kesulitan yang muncul selama proses pencarian pekerjaan seringkali terjadi karena individu tidak memiliki arah karir yang jelas. Selain itu, saat ini para penyedia pekerjaan juga lebih selektif dalam mencari dan memilih calon karyawannya. Pilihannya adalah pada individu yang memiliki satu set ketrampilan yang berguna untuk dapat beradaptasi dalam berbagai lingkungan yang kerap berubah (Ballout, 2009). Konsekuensinya adalah kenyataan bahwa para pencari kerja dituntut untuk mampu mengembangkan strategi dan perilaku baru agar dapat membantunya mengem-bangkan karir.

Pentingnya karir bagi seseorang menuntut adanya persiapan yang baik sehingga individu tidak akan mengalami berbagai kesulitan yang berarti, dalam hal ini pengetahuan yang relevan dengan karir menjadi hal yang penting. Sebelum melakukan pencarian informasi karir, seseorang perlu membenahi keyakinannya dalam pengambilan keputusan karir tetapi banyak kesulitan terjadi dalam pengambilan keputusan karir karena harus mempertimbangkan berbagai perubahan yang terjadi di dunia kerja. Perubahan tersebut antara lain perubahan teknologi dan ekonomi global (Tansley, Jore, Haase \& Martens, 2007).

Banyaknya tantangan semakin mempersulit seseorang untuk membuat keputusan karir. Kesulitan dalam membuat keputusan karir ini berhubungan 
dengan bagaimana seseorang menilai kemampuan dirinya dalam menghadapi tantangan tersebut. Bandura (1997) mengistilahkannya sebagai efikasi diri (selfefficacy) yang merupakan penilaian atas kemampuan diri dalam mengatur dan melaksanakan berbagai jenis perilaku berkinerja atas suatu hal tertentu, sedangkan harapan atas hasil adalah penilaian atas konsekuensi yang dihasilkan oleh perilaku berkinerja. Dapat disimpulkan bahwa kinerja adalah suatu penyelesaian dan hasil adalah sesuatu yang mengikuti kinerja. Bandura melanjutkan bahwa bila kinerja menentukan sebuah hasil, maka tingkat keyakinan terhadap efikasi memberi kontribusi atas berbagai perbedaan hasil yang diinginkan. Saat keyakinan atas efikasi dikendalikan, harapan atas hasil menjadi tidak atau sedikit berpengaruh secara independen untuk memprediksi perilaku.

Orang yang memiliki efikasi diri yang tinggi menganggap tugas-tugas sulit sebagai tantangan yang harus dilalui dibandingkan sebagai ancaman yang harus dihindari (Krapp, 2005). Mereka juga menetapkan tujuan yang menantang bagi mereka sendiri, serta menjaga komitmen yang kuat untuk mencapainya. Ketika mengalami kemunduran atau kegagalan, maka mereka dapat memperbaiki kepercayaan diri secara cepat dan kemudian melipatgandakan usahanya. Apabila dikaitkan dengan penentuan keputusan karir, maka dapat disimpulkan bahwa seseorang dengan efikasi diri yang tinggi dapat lebih yakin dalam menentukan karir yang diinginkan meskipun banyak terjadi perubahan di lingkungan sekitarnya.

Berdasarkan hal tersebut, peneliti tertarik untuk mengetahui lebih jauh bagaimana dampak manipulasi berbagai sumber efikasi diri dalam membuat keputusan karir. Cara yang ditempuh adalah dengan mengembangkan suatu intervensi yang dapat meningkatkan efikasi diri dalam pengambilan keputusan karir. Para ahli telah membuat sebuah konstruk yang utuh untuk menjelaskan efikasi diri dalam membuat keputusan karir atau career decision-making self-efficacy (CDMSE). Taylor dan Betz (1983) adalah ahli yang pertama membuat konstruk tersebut. Taylor dan Betz mendefinisikan efikasi diri dalam membuat keputusan karir sebagai sebuah keyakinan individu untuk dapat dengan sukses menyelesaikan tugastugas yang dibutuhkan untuk membuat keputusan karir (Paulsen \& Betz, 2004).

Penelitian sebelumnya menunjukan bahwa siswa yang mengalami kebimbangan karir atau rendahnya efikasi diri dalam membuat keputusan karir juga menunjukkan adanya rasa tidak percaya diri dalam kemampuan dasar secara akademik (Paulsen \& Betz, 2004). Merujuk pada formulasi Bandura serta pendapat Paulsen dan Betz, dapat digeneralisasikan dua pendapat tersebut dalam konteks berbeda, yaitu konteks pekerja di dalam perusahaan. Seorang pekerja yang memiliki kebimbangan karir akan cenderung merasa tidak percaya diri dengan kemampuan dasarnya dalam karir atau pekerjaan yang ia miliki. Lunenburg (2011) menguatkan 
pendapat di atas dengan pendapat bahwa dengan memiliki efikasi yang tinggi maka akan dapat memengaruhi tingkat usaha dan kegigihan saat mempelajari atau mengerjakan tugas-tugas yang sulit. Tentu hal ini membawa konsekuensi pada perusahaan untuk meningkatkan efikasi diri karyawan dalam membuat keputusan karirnya sehingga kelak perusahaan memiliki aset yang kuat untuk mencapai tujuan organisasi. Hal ini dikarenakan karyawan dengan efikasi diri yang tinggi tidak akan segan untuk mengerjakan pekerjaan yang sulit dan mampu menunjukkan kegigihan untuk menyelesaikan tugas-tugas yang diberikan asalkan hal tersebut masih relevan dengan karirnya.

George dan Cristiani (1990) membuktikan ketrampilan untuk membuat keputusan karir adalah suatu hal yang dapat dipelajari secara sistematis, artinya dimungkinkan bagi para praktisi untuk mengembangkan program-program pengembangan karir individu. Penelitian sebelumnya telah menunjukkan bagaimana pelatihan, konseling (Koivisto, Vinokur \& Vuori, 2011; Mulyana, 2009), kursus karir (Scott \& Ciani, 2008; Fouad, Cotter \& Kantamneni, 2009) terbukti mampu meningkatkan efikasi diri dalam membuat keputusan karir. Penelitian lain juga sejalan antara lain O'Brien, Bikos, Epstein, Flores, Dokstein dan Kamatuka (2000) yang menyarankan bahwa perlu adanya program eksplorasi karir untuk meningkatkan rasa percaya diri seseorang. Di dalam program tersebut diharapkan ada proses mencari tahu, menyeleksi dan mengimplementasikan karir yang telah dipilih.

Penelitian ini mencoba memperkuat metode sebelumnya dengan memberikan ruang bagi para peserta untuk belajar dari pengalaman orang lain dan saling berbagi pengetahuan agar dapat memunculkan inovasi dan solusi yang lebih baik atas hambatan yang mungkin dialami dalam membuat keputusan karir. Metode yang peneliti tawarkan salah satunya didasari oleh hasil penelitian Greenbank dan Hepworth (2008a) yang menunjukkan bahwa aktivitas yang melibatkan studi kasus, analogical coding (membandingkan dua hal untuk memahami kesamaannya) dan kerja kelompok merupakan cara terbaik untuk mendorong seseorang agar dapat secara kritis mengevaluasi cara mereka dalam mengambil keputusan karir. Nawaz dan Gilani (2011) menambahkan bahwa selain adanya dukungan teman sebaya, faktor dukungan orang tua juga dapat berpengaruh secara positif pada keyakinan seseorang dalam membuat keputusan karir. Berdasarkan hal tersebut maka intervensi yang dibuat harus mampu mengakomodir ketersediaan dukungan teman sebaya, yaitu dengan menyediakan kelompok yang dikondisikan untuk saling mendukung satu sama lain.

Pentingnya menyediakan kelompok dalam intervensi karir juga diperkuat dengan hasil penelitian Wang, Zhang dan Shao (2010) bahwa training kelompok dapat secara efektif meningkatkan keyakinan seseorang dalam membuat kepu- 
tusan karir serta dapat membantu seseorang dalam merencanakan pengembangan karir .

Berdasarkan beberapa hasil penelitian di atas peneliti menggunakan metode berbagi pengetahuan sebagai metode intervensi. Berbagi pengetahuan dalam perencanaan karir dimungkinkan dapat dilakukan karena menurut King (2006) pengetahuan adalah sesuatu yang dapat dibagi antar individu dan di antara individu-individu, dalam kelompok dan antar kelompok serta unit organisasi dan antar organisasi.

Efektivitas berbagi pengetahuan ini ditandai dengan adanya peningkatan pengetahuan dari anggotanya. Terbentuknya pengetahuan baru menjadi efektif saat mampu menciptakan sebuah inovasi. Menurut Krathwohl (2002), sebuah penciptaan membutuhkan kemampuan untuk menyatukan berbagai elemen menjadi sesuatu yang baru namun masih terkait ataupun membuat sesuatu yang sama sekali baru. Krathwohl juga menambahkan bahwa penciptaan ini melibatkan tiga proses kognitif, yaitu (1) pembangkitan, membuat hipotesa alternatif berdasarkan kriteria yang ada; (2) perencanaan, yaitu merencanakan metode yang paling tepat untuk menyelesaikan tugas tertentu dalam hal ini adalah membuat perencanaan yang tepat untuk mengeksekusi solusi alternatif yang telah dibuat; dan (3) penciptaan, yaitu proses akhir di mana sebuah produk baru dihasilkan.

Pengetahuan dapat dibagi kepada setiap peserta dengan tujuan menciptakan meningkatkan pemahaman peserta dan menciptakan berbagai solusi. Denning (2004) juga menyatakan pendapatnya bahwa menangkap apa yang sudah diketahui oleh orang lain dalam kelompok dan menambahkan pengetahuan sendiri seringkali lebih cepat dan efisien dibandingkan dengan menciptakan kembali solusi-solusi sendirian. Selain itu banyak penulis dan ahli pendidikan menyetujui bahwa belajar adalah sebuah aktivitas sosial dan tempat terbaik untuk belajar adalah di dalam kelompok (Buckley \& Giannakopoulos, 2011).

Sesuai dengan pendapat di atas, yaitu bahwa belajar adalah aktivitas sosial dan proses belajar yang paling baik adalah dalam kelompok maka penelitian ini menggunakan prinsip-prinsip dalam kelompok praktek atau community of practice (CoP) sebagai dasar pembuatan kelompok untuk saling berbagi pengetahuan. Istilah kelompok praktek dalam dunia industri telah dipakai secara luas namun masih belum ada definisi yang secara pasti dapat menggambarkan CoP dengan jelas. Kelompok praktek pertama digunakan oleh Lave dan Wenger (1991) untuk menggambarkan pembelajaran melalui praktek dan partisipasi, yang mereka sebut sebagai situated learning. Mereka menegaskan bahwa situated learning bukanlah bentuk institusi pendidikan namun lebih pada bentuk strategi pendidikan. CoP selain lazim digunakan juga merupakan cara yang efektif untuk meningkatkan kerjasama antar pekerja pengetahuan (Yang \& Wei, 2010) dan 
Retna (2010) telah membuktikan bahwa CoP mampu memfasilitasi kreasi, kegiatan berbagi (Goel, Junglases \& Ives, 2009) dan penggunaan pengetahuan dalam organisasi yang secara positif memengaruhi strategi, operasi dan bottom line. Goel dan kawan-kawan (2009) menjelaskan bahwa CoP menjadi salah satu media yang mampu memfasilitasi berbagai pengetahuan. Atas dasar inilah peneliti mengajukan intervensi yang menggunakan prinsip-prinsip dalam CoP sehingga kegiatan berbagi pengetahuan dapat difasilitasi dengan maksimal untuk meningkatkan efikasi diri dalam membuat keputusan karir.

Wenger (2010) berpendapat bahwa pembelajaran yang berada dalam batas sistem haruslah memiliki keseimbangan antara kompetensi dan pengalaman yang sama di antara anggotanya. Orang-orang dalam CoP dapat saling berbagi pengetahuan dan belajar banyak hal dari anggota yang lain sehingga semakin paham dengan pengetahuan yang dimiliki. Hal ini diperkuat dengan pendapat Lesser dan Storck (2001) bahwa salah satu fungsi CoP adalah untuk mengurangi kurva belajar karyawan baru (artinya belajar dapat menjadi lebih efisien). Berdasarkan penelitian Jeon, Kim dan Koh (2011) diketahui bahwa berbagi pengetahuan dipengaruhi oleh faktor motivasi internal maupun eksternal namun lebih jauh dikemukakan bahwa motivasi internal akan memiliki pengaruh yang lebih kuat. Hal ini sejalan dengan Choi, Kang dan Lee (2008) yang menemukan bahwa kegiatan berbagi pengetahuan dapat difasilitasi dengan mengoptimalkan pengungkit sosial seperti rasa percaya dan mekanisme pengupahan karena hal ini lebih penting dibandingkan dukungan teknis lainnya. Sedangkan perilaku berbagi pengetahuan dalam perusahaan sangat dipengaruhi oleh budaya organisasi sedangkan untuk negatif atau positifnya tergantung dari tipe budaya yang dianut (Suppiah \& Sandhu, 2011).

Berdasarkan penelitian Nickols (2000) ada dua jenis CoP, yaitu yang diorganisir sendiri dan yang disponsori (Buckley \& Giannakopoulos, 2011). Pada dasarnya keduanya memiliki tujuan yang sama yaitu memfasilitasi berbagi pengetahuan. Jenis yang paling cocok untuk kepentingan penelitian ini adalah CoP yang disponsori dan tujuan utama dari CoP ini peneliti adaptasi dari Buckley dan Giannakopoulos (2011), yaitu (1) Memberi ruang kepada para peserta untuk dapat belajar satu sama lain melalui berbagi topik, ide, hasil pembelajaran, masalah dan solusi, temuan penelitian dan aspek lain yang terkait untuk kepentingan bersama; (2) Menyediakan media untuk rdapat lebih menyebarluaskan dan memanfaatkan pembelajaran yang didapat dalam kelompok dengan rekan lainnya; (3) Menghasilkan hasil nyata yang terukur, memberi manfaat dan nilai tambah pada setiap peserta.

Melalui penelitian ini peneliti ingin mengetahui lebih jauh bagaimana pengaruh berbagi pengetahuan dalam perencanaan karir terhadap efikasi diri dalam 
membuat keputusan karir para pencari kerja. Hipotesis penelitian ini adalah bahwa dengan melakukan berbagi pengetahuan dalam perencanaan karir akan dapat meningkatkan efikasi diri dalam membuat keputusan karir para pencari kerja.

\section{METODE PENELITIAN}

\section{Rancangan Penelitian}

Peneliti menggunakan desain penelitian quasi experiment the untreated control group with dependent pre-test and post-test (Shadish, Cook \& Campbell, 2010) karena adanya pemilihan subjek penelitian yang dilakukan secara purposive sampling dan ketersediaan subjek yang terbatas. Kelompok eksperimen dalam penelitian ini diberi manipulasi berupa kegiatan berbagi pengetahuan untuk memperkuat efikasi diri dalam membuat keputusan karir. Kedua kelompok sama-sama diberi prates sebelum perlakuan, kemudian diberikan pascates setelah perlakuan. KK menjadi waiting list dan diberikan perlakuan yang sama dengan KE setelah penelitian selesai.

Tabel 1. Rancangan eksperimen

\begin{tabular}{ccccc}
\hline Kelompok & Kondisi & Prates & Perlakuan & Pascates \\
\hline$($ KE) & NR & 01 & $X$ & 02 \\
$($ KK) & NR & 01 & & 02 \\
\hline
\end{tabular}

Keterangan:

KE : (kelompok eksperimen)

KK : (kelompok control

O1 : prates

$\mathrm{O} 2$ : pascates

$X$ : perlakuan berbagi pengetahuan

- : tidak diberi perlakuan

\section{Subjek Penelitian}

Partisipan yang terlibat dalam penelitian ini adalah lulusan S1 perguruan tinggi baik lulusan baru ataupun sudah bekerja kurang dari 3 tahun yang sedang mencari pekerjaan ataupun ingin berganti pekerjaan. Peserta yang berminat untuk mengikuti kegiatan ini diminta untuk melakukan registrasi secara online sekaligus melakukan pengisian prates. Hasil skor prates dikategorisasi untuk menentukan partisipan sesuai kriteria. Sebelum penelitian dijalankan, peneliti mengundang 40 orang calon peserta kelompok eksperimen dan 40 orang calon kelompok eksperimen pada waktu yang berbeda untuk memberi penjelasan teknis penelitian.

Penentuan calon peserta dilakukan secara purposive sampling dan jumlah orang di dalam tiap kelompok ditentukan dengan memperhatikan komposisi peserta dengan skor rendah, sedang dan tinggi serta ketersediaan waktu subjek. Peserta yang berkenan datang memenuhi undangan adalah 38 orang untuk kelompok eksperimen dan 27 orang untuk kelompok kontrol. Selama proses intervensi berlangsung, 8 orang peserta dinyatakan tidak dapat dianalisis datanya karena gugur. Merea dinyatakan gugur karena beberapa alasan, antara lain harus mengikuti seleksi kerja di perusahaan serta tidak mengikuti sesi-sesi intervensi secara penuh. Pada akhirnya peserta penelitian ini berjumlah 57 orang yang terdiri atas 30 orang kelompok eksperimen dan 27 orang kelompok kontrol. Peneliti membatasi usia peserta dengan 
kisaran umur 21 tahun hingga 25 tahun untuk menurunkan pengaruh perbedaan umur terhadap variabel tergantung. Selain itu, menurut Isik (2010), subjek dengan umur 21 tahun ke atas terbukti lebih mudah mengerjakan tugas-tugas dalam membuat keputusan karir dibandingkan subjek yang lebih muda. Peserta yang mengikuti penelitian ini hanyalah orangorang yang memang bersedia untuk mengikuti kegiatan berbagi pengetahuan yang dinyatakan dengan mengisi informed consent.

\section{Metode Pengumpulan Data}

Pengumpulan data dalam penelitian ini menggunakan skala efikasi diri, yaitu dalam membuat keputusan karir (CDSE Versi Indonesia). Alat ukur yang peneliti gunakan berdasarkan pada alat ukur CDMSE-SF (Betz, Hammond \& Multon ,2005; Betz \& Taylor, 2001). Skala CDMSE-SF sebelumnya banyak digunakan untuk mengukur efikasi diri dalam membuat keputusan karir dengan menggunakan siswa SMA (ataupun mahasiswa perguruan tinggi sebagai subjeknya) sehingga aitem-aitem sebelumnya tidak lagi relevan dengan kebutuhan penelitian ini. Peneliti melakukan adaptasi terhadap skala CDMSE-SF disesuaikan dengan karakteristik subjek dalam penelitian ini.

Peneliti mengubah nama skala yang baru menjadi CDSE Versi Indonesia dengan menggunakan 5 level respon. Respon skala CDSE Versi Indonesia menggunakan model summated rating atau model Likert. Respon dimulai dari level 1 (tidak percaya diri) hingga level 5 (sangat percaya diri). Betz, Hammond dan Multon (2005) telah membuktikan bahwa CDMSE-SF dengan 25 aitem dan 5 level respon diakui tetap reliabel dan valid untuk mengukur efikasi diri dalam membuat keputusan karir sama seperti skala aslinya yang menggunakan 50 aitem dan 10 respon. Penelitian Betz dkk tersebut menggunakan sampel mahasiswa sejumlah 1.832 partisipan dan dengan koefisien alpha bergerak antara 0,78 sampai 0,87. Hasil analisis reliabilitas penelitian Reese dan Miller (2006) juga menunjukkan bahwa alat ukur ini memiliki konsistensi internal dengan koefisien alpha 0,94 untuk skala keseluruhan kemudian untuk sub skala bergerak antara 0,74 (menilai diri secara akurat) hingga 0,89 (seleksi tujuan). Penelitian terbaru (Nam, Yang, Lee, Lee \& Seol, 2010) ketika menggunakan 370 mahasiswa Korea mampu menunjukkan konsistensi internal yang baik dengan koefisien alpha 0,92 dan untuk masing-masing sub skala bergerak antara lain 0,76 (menilai diri secara akurat), 0,68 (pengumpulan informasi tentang pekerjaan), 0,75 (seleksi tujuan), 0,79 (perencanaan masa depan), dan 0,70 (pemecahan masalah).

Skala CDSE Versi Indonesia ini terdiri atas 25 aitem hasil terjemahan dari skala asli. Peneliti melakukan perbaikan bahasa disesuaikan dengan subjek penelitian namun tidak mengubah substansi dari aitem-aitem skala asli agar validitasnya tetap terjaga. CDSE Versi Indonesia ini sama dengan versi aslinya yang 
bertujuan mengukur aspek-aspek dalam efikasi diri dalam membuat keputusan karir dari Crites (1978) antara lain melakukan penilaian diri secara akurat, pengumpulan informasi tentang pekerjaan, menyeleksi tujuan, membuat rencana untuk masa depan, dan pemecahan masalah. Salah satu contoh aitemnya antara lain, sebera-pa percaya dirikah anda dalam: Menent-ukan pekerjaan yang paling ideal bagi anda sendiri.

Skor total skala ini adalah skor yang menunjukkan tingkat efikasi diri seseorang dalam membuat keputusan karir. Semakin tinggi skor yang diperoleh individu maka semakin tinggi pula efikasi dirinya dalam membuat keputusan karir. Taylor dan Betz (1983) telah melakukan analisis faktor pada skala yang diadaptasi dalam penelitian ini dan menemukan bahwa instrumen ini memiliki validitas yang baik dalam mengukur faktor-faktor efikasi diri dalam membuat keputusan karir. Hasil analisis faktor ini mengungkap beberapa faktor atau sub faktor efikasi diri dalam membuat keputusan karir namun tidak menyarankan untuk melakukan analisis berdasarkan hasil masing-masing sub faktor sebagai prediktor kebimbangan kejuruan.

Peneliti melakukan uji coba skala CDSE Versi Indonesia dengan sebelumnya melakukan penyesuaian bahasa dan istilah dalam skala tanpa mengubah substansi untuk menjaga validitas alat ukur. Uji coba melibatkan 68 partisipan yang sesuai dengan kriteria yaitu lulusan S1 perguruan tinggi baik lulusan baru ataupun sudah bekerja kurang dari 3 tahun yang sedang mencari pekerjaan ataupun ingin berganti pekerjaan. Reliabilitas skala diuji dengan teknik formula Cronbach's Alpha. Hasil menunjukkan bahwa nilai reliabilitas alpha skala adalah 0,904 . Hanya ada 1 aitem yang tidak memenuhi persyaratan (dengan korelasi aitem 0,288 namun aitem ini tetap peneliti gunakan dengan pertimbangan bahwa jika aitem dihilangkan tidak secara signifikan memengaruhi nilai reliabilitas alpha skala $r$ yaitu hanya naik 0,001 menjadi 0,905 . Tidak ada satu pun aitem yang gugur dari keseluruhan 25 aitem dengan koefisien korelasi aitem total antara 0,288-0,654.

\section{Intervensi}

Intervensi dilakukan dalam tiga tahap, yaitu persiapan, pelaksanaan, dan evaluasi. Tahap persiapan meliputi pelak-sanaan prates, seleksi subjek penelitian dan informed consent. Pada tahap persiapan penelitian, peneliti berdiskusi dengan fasilitator untuk membahas mekanisme penelitian. Peneliti bersama tim melakukan promosi terkait kegiatan ini di antaranya dengan melakukan promosi di Website ECC, Email, ECC SMS Booster, Twitter ECC dan pamflet. Target peserta adalah anggota dari ECC yang telah lulus S1.

Prates dilakukan secara online kepada anggota ECC yang berminat untuk mengikuti kegiatan ini. Data isian yang telah terkumpul diskor dan dikategorisasi untuk mendapatkan kelompok data de- 
ngan skor rendah, sedang dan tinggi. Bagi peserta yang tidak memenuhi criteria, maka tidak berkesempatan untuk mengikuti kegiatan ini.

Peserta yang telah memenuhi kriteria kemudian dipilih untuk mengikuti batch 1. Informasi kegiatan disebarluaskan melalui SMS dan via telepon kepada calon peserta terpilih. Bagi peserta yang bersedia mengikuti kegiatan ini dari awal hingga akhir diminta untuk mengisi informed consent dan demographic questionaire. Demographic questionaire juga digunakan sebagai cek manipulasi sebelum penelitian untuk memastikan bahwa calon peserta belum pernah mengikuti kegiatan sejenis dalam kurun waktu 6 bulan.

Penentuan kelompok bagi calon peserta yang telah sesuai dengan kriteria dilakukan dengan mempertimbangkan ketersediaan waktu calon peserta untuk menghindari tidak datangnya peserta saat pelaksanaan intervensi. Calon peserta yang sesuai dengan kriteria namun tidak berkesempatan mengikuti batch 1 dimasukkan dalam kelompok kontrol dan tetap berkesempatan mengikuti intervensi yang sama di batch 2 sedangkan untuk hasil intervensi pada batch 2 tidak akan dianalisis.

Tahap pelasanaan Intervensi. Intervensi dalam penelitian ini adalah kegiatan berbagi pengetahuan, berupa serangkaian kegiatan yang diselenggarakan untuk memfasilitasi penyebaran pengetahuan dan penyerapan pengetahuan antar anggota kelompok. Peneliti mengembang- kan modul berbagi pengetahuan dalam perencanaan karir dengan materi yang didasarkan pada aspek-aspek dari Crites (1978). Tujuannya adalah untuk meningkatkan kemampuan dalam mengambil keputusan karir dan membantu memfasilitasi pertumbuhan karir setiap individu didalamnya.

Uji modul peneliti lakukan untuk memastikan materi yang diberikan benarbenar dapat tersampaikan dengan baik sehingga tujuan penelitian ini dapat tercapai. Uji modul menghadirkan trainer dan para fasilitator untuk melakukan role play dan diskusi terkait teknis pelaksanaan dan materi yang akan disampaikan. Setelah uji modul dilakukan, peneliti melakukan perbaikan modul dengan menyesuaikan durasi kegiatan, materi ajar, video, games, lembar isian dan lainlain sehingga kegiatan ini menjadi lebih padat. Kegiatan ini berlangsung empat hari dengan satu sesi training sebagai bentuk pengkondisian awal dan tiga sesi berbagi pengetahuan dalam kelompok kecil.

Kegiatan perencanaan karir ini mengangkat judul Your Ultimate Career: Share it, Understand it and Love it. Peserta diikutkan dalam serangkaian kegiatan berupa satu kali sesi pelatihan dan tiga kali sesi sharing dalam kelompok kecil. Kegiatan ini diawali dengan pelaihan Effective Knowledge Sharing selama 9 jam kemudian hari ke 2, 4 dan 5 merupakan sesi berbagi (sesi 1-3) selama 4 jam untuk masing-masing sesi. Kegiatan ini dilakukan selama 5 hari dengan jeda 
pada hari ketiga atau tidak ada kegiatan pada hari tersebut.

Sebagai bentuk cek manipulasi selama proses penelitian, peserta diminta untuk selalu menuliskan kembali hal-hal yang telah dipelajari pada hari tersebut dalam Lembar Refleksi yang telah disediakan oleh peneliti. Selain itu peserta juga diberikan tugas yang harus dilakukan diluar sesi berbagi pengetahuan. Salah satu contohnya adalah tugas untuk mencari berbagai informasi karir yang relevan dengan kebutuhan rekan sekelompok dan peserta diminta untuk mengiformasikan kepada yang bersangkutan melalui SMS.

Pada sesi pelatihan Effective Knowledge Sharing, peserta diajar pentingnya pengetahuan yang relevan untuk karirnya dan belajar cara yang efektif dalam berbagi pengetahuan untuk meningkatkan kemampuannya. Sesi pertama dengan materi Creative Problem Solver ditujukan untuk membekali peserta dengan ketrampilan memecahkan masalah secara efektif dan kreatif sehingga peserta mampu memahami berbagai permasalahan karir dan mampu mengembangkan solusi yang paling efektif untuk menyelesaikannya. Sesi ini dilanjutkan dengan materi Self Mastery. Peserta akan belajar memahami diri melalui identifikasi keahlian, sifat, minat dan nilai-nilai diri yang dimiliki untuk mencapai karir yang dinginkan. Sesi kedua berisikan materi The Power of Information ditujukan untuk meningkatkan kemampuan peserta dalam mengumpulkan informasi yang relevan dengan karirnya.
Sesi terakhir berupa materi The Ultimate Goal for The Ultimate Career untuk menanamkan pemahaman kepada peserta akan pentingnya membuat tujuan yang efektif dan membekali mereka dengan metode terbaik untuk membuat tujuan. Pentingnya memiliki orientasi tujuan telah diteliti oleh Garcia, Restubog, Toledano, Tolentino dan Rafferty (2011) dan terbukti berbanding positif dengan efikasi diri dalam membuat keputusan karir. Materi kedua disesi terakhir adalah tentang Future Career Plans. Materi ini disajikan agar peserta dapat menjaga agar karirnya sesuai dengan jalurnya melalui perencanaan kegiatan ke depan yang disusun oleh peserta sendiri.

Pelaksanaan intervensi dilakukan oleh tim yang terdiri atas satu trainer yang mengisi sesi pelatihan Effective Knowledge Sharing. Trainer adalah dosen dan psikolog ataupun trainer profesional yang telah memiliki pengalaman minimal lima tahun dalam memberikan pelatihan dan berpengalaman memberikan intervensi dalam kelompok. Kemudian untuk sesi sharing difasilitasi oleh fasilitator yang merupakan mahasiswa tingkat akhir Magister Psikologi Profesi yang telah memiliki pengalaman menjadi fasilitator diskusi kelompok minimal dua tahun. Selain itu fasilitator juga bertugas untuk melakukan observasi kegiatan berbagi pengetahuan dan memberikan umpan balik kepada peserta bila peserta kurang aktif dalam sesi-sesi sharing. 
Peneliti menyadari adanya ancaman terhadap validitas internal penelitian yang sulit dikontrol, di antaranya kemungkinan hilangnya subjek penelitian dan kondisi lingkungan misalnya, hujan deras ataupun cuaca yang panas. Kemudian untuk mengurangi kemungkinan tersebut, peneliti melakukan penyesuaian durasi intervensi menjadi lebih singkat dengan materi yang lebih padat. Hal ini cukup efektif mengingat aktivitas peserta yang relatif padat dengan jadwal kegiatan seleksi perusahaan. Dampak lain yang harus jadi perhatian adalah kedalaman pemahaman dengan adanya waktu yang singkat tersebut. Selain itu bagi peserta yang tidak dapat mengikuti salah satu sesi tetap dibolehkan mengikuti kegiatan namun hasil tidak akan dianalisis. Pertimbangannya adalah bila peserta tidak diperbolehkan mengikuti sesi selanjutnya dikhawatirkan mengganggu dinamika kelompok, mengingat peserta dibagi dalam kelompok kecil. Kemudian untuk faktor cuaca, tidak dapat peneliti kontrol karena adanya keterbatasan tempat saat intervensi dilakukan.

Tahap terakhir adalah evaluasi. Evaluasi dilakukan dengan pascates. Setelah seluruh sesi berakhir peserta diminta untuk mengisi pascates (O2). Pascates diberikan langsung setelah semua sesi berakhir untuk menghindari berkurang- nya. Subjek pada penelitian ini rentan untuk gugur atau mudah meninggalkan proses intervensi dengan alasan kegeiatan rekrutmen atau proses seleksi pekerjaan. Skala CDSE Versi Indonesia yang digunakan dimodifikasi tampilan dan penomoran aitem untuk mengurangi efek pembelajaran atas alat ukur sebelumnya.

\section{Metode analisis data}

Analisis data kuantitatif dilakukan dengan menggunakan anava campuran (mixed anova). Teknik analisis ini digunakan untuk membandingkan efikasi diri terhadap keputusan karir sebelum dan sesudah perlakuan antara kelompok eksperimen dan kelompok kontrol. Teknik analisis ini dalamnya memadukan dua sub analisis yaitu Within Subject Test dan Between Subject Test. Within Subject Test adalah pengujian perbedaan skor dalam satu kelompok (prates dengan pascates) dan Between Subject Test adalah pengujian perbedaan skor antar kelompok (eksperimen dengan kontrol).

\section{HASIL PENELITIAN}

\section{Deskripsi Statistik}

Berdasarkan hasil analisis diperoleh data statistik deskriptif yang disajikan dalam tabel berikut ini. 
Tabel 2. Deskripsi Data

\begin{tabular}{llccc}
\hline & Group & Mean & Std. Deviation & $\mathrm{N}$ \\
\hline \multirow{3}{*}{ Prates } & Eksperimen & 83,63 & 11,491 & 30 \\
& Kontrol & 87,78 & 12,442 & 27 \\
& Total & 85,60 & 12,025 & 57 \\
\hline \multirow{3}{*}{ Pascates } & Eksperimen & 95,43 & 10,006 & 30 \\
& Kontrol & 85,74 & 13,487 & 27 \\
& Total & 90,84 & 12,654 & 57 \\
\hline
\end{tabular}

Tabel di atas menunjukkan bahwa rerata prates kelompok eksperimen sebesar 83.63 dan rerata pascates sebesar 95.43. Hal ini menunjukkan bahwa terjadi peningkatan efikasi diri dalam membuat perencanaan karir setelah dilakukan intervensi sebesar 11.8. Sementara itu pada keolompok kontrol terjadi penurunan rerata efikasi diri dalam membuat keputusan karir sebesar 2,04 dengan prates sebesar 87,78 dan pascates sebesar 85,74 .

\section{Hasil Uji Prasyarat}

Uji prasyarat dengan menguji normalitas dan homogenitas data dilakukan sebelum melakukan pengujian hipotesis. Pengujian ini didasari oleh asumsi dasar parametrik, yakni data terdistribusi normal dan nilai variannya homogen. Uji normalitas dilakukan dengan menggunakan teknik statistik one sample Kolmogorov Smirnov. Setelah analisis dilakukan dike- tahui bahwa hasil $\mathrm{K}-\mathrm{Z}=0,750$ dengan $\mathrm{p}$ $=0,627(p>0,05)$ untuk data prates dan $\mathrm{K}-\mathrm{Z}=0,852$ dengan $\mathrm{p}=0,462(\mathrm{p}>0,05)$ untuk data pascates. Sesuai dengan kaidah yang digunakan dengan nilai $p>$ 0,05, maka disimpulkan bahwa data terdistribusi normal. Uji homogenitas dilakukan dengan teknik statistik Box's Test dan diperoleh hasil Box's $M=7,742$ dan $p=0,059 \quad(p>0,05)$ sehingga dapat disim-pulkan bahwa sebaran data adalah homogen dan berasal dari varian data yang sama.

\section{Hasil Uji Hipotesis}

Hipotesis yang diajukan dalam penelitian ini adalah bahwa berbagi pengetahuan dalam perencanaan karir dapat meningkatkan efikasi diri dalam membuat keputusan karir para pencari kerja. Hipotesis ini diuji dengan menggunakan anava campuran, sebagaimana terlihat hasilnya dalam tabel berikut. 
Tabel 3. Tests of Within-Subjects Effects

\begin{tabular}{llcccccc}
\hline & Source & $\begin{array}{c}\text { Type III } \\
\text { Sum of } \\
\text { Squares }\end{array}$ & Df & $\begin{array}{c}\text { Mean } \\
\text { Square }\end{array}$ & $F$ & Sig. & $\begin{array}{c}\text { Partial Eta } \\
\text { Squared }\end{array}$ \\
\hline Time * $^{*}$ & Sphericity Assumed & 1360,399 & 1 & 1360,399 & $22,736,000$ &, 292 \\
Group & Greenhouse-Geisser & 1360,399 & 1,000 & 1360,399 & $22,736,000$ &, 292 \\
& Huynh-Feldt & 1360,399 & 1,000 & 1360,399 & $22,736,000$ &, 292 \\
& Lower-bound & 1360,399 & 1,000 & 1360,399 & $22,736,000$ &, 292 \\
\hline
\end{tabular}

Pada baris Time*Group dan sub baris Greenhouse-Geisser dari tabel Tests of Within-Subjects Effects terlihat hasilnya adalah $F=22,736 \quad(p<0,00)$. Hal ini berarti bahwa terdapat interaksi antara time (pre-post test) dan group (eksperi- men-kontrol). Interaksi tersebut menunjukkan bahwa perubahan skor prates menuju pascates pada kedua kelompok (eksperimen-kontrol) adalah berbeda secara signifikan.

Tabel 4. Pairwise Comparison

\begin{tabular}{|c|c|c|c|c|c|c|c|}
\hline \multirow[t]{2}{*}{ Group } & \multirow{2}{*}{\multicolumn{2}{|c|}{ (I) time (J) time }} & \multirow[t]{2}{*}{$\begin{array}{c}\text { Mean } \\
\text { Difference (I-J) }\end{array}$} & \multirow[t]{2}{*}{ Std. Error } & \multirow[t]{2}{*}{ Sig. $^{a}$} & \multicolumn{2}{|c|}{$\begin{array}{c}\text { 95\% Confidence Interval for } \\
\text { Difference }^{\mathrm{a}}\end{array}$} \\
\hline & & & & & & Lower Bound & Upper Bound \\
\hline \multirow[t]{2}{*}{ Eksperimen } & 1 & 2 & $-11,800^{*}$ & 1,997 &, 000 & $-15,803$ & $-7,797$ \\
\hline & 2 & 1 & $11,800^{*}$ & 1,997 & ,000 & 7,797 & 15,803 \\
\hline \multirow[t]{2}{*}{ Kontrol } & 1 & 2 & 2,037 & 2,105 & ,337 & $-2,182$ & 6,256 \\
\hline & 2 & 1 & $-2,037$ & 2,105 & ,337 & $-6,256$ & 2,182 \\
\hline
\end{tabular}

Setelah diketahui bahwa terjadi interaksi yang signifikan antara time (prepost test) dan group (eksperimen-kontrol), maka langkah selanjutnya adalah melihat efektivitas intervensi. Tabel di atas menunjukkan bahwa perubahan efikasi diri dalam membuat keputusan karir pada kelompok eksperimen adalah signifikan $(M D=-11,800 ; p<0,05)$. Sementara itu perubahan efikasi diri dalam membuat keputusan karir pada kelompok kontrol adalah tidak signifikan $(M D=2,037$; $p>0,05)$. Hal ini menunjukkan bahwa berbagi pengetahuan dalam perencanaan karir secara efektif dapat meningkatkan efikasi diri dalam membuat keputusan karir para pencari kerja. Peningkatan skor pada kelompok eksperimen adalah 11,800 sedangkan pada kelompok kontrol meski tidak signifikan terjadi penurunan skor sejumlah 2,037. 
Tabel 5. Multivariate Tests

\begin{tabular}{lcccccc}
\hline & \multicolumn{5}{c}{ Hypothesis } & \multirow{2}{*}{ Partial Eta } \\
Group & Value & $F$ & $d f$ & Error df Sig. & Squared \\
\hline Eksperimen & Wilks' lambda & 612 & $34,906^{\mathrm{a}}$ & 1,000 & $55,000,000$ &, 388 \\
\hline Kontrol & Wilks' lambda & 983 &, $936^{\mathrm{a}}$ & 1,000 & $55,000,337$ &, 017 \\
\hline
\end{tabular}

Selanjutnya adalah sumbangan efektif intervensi terhadap peningkatan efikasi diri dalam membuat keputusan karir, diketahui dari tabel Multivariat Test pada kolom Wilks Lamda di atas. Pada kolom tersebut untuk kelompok kontrol menunjukkan nilai Partial Eta Square 0,388 atau sumbangan efektifnya sebesar $38,8 \%$.

\section{PEMBAHASAN}

Penelitian ini bertujuan untuk melihat apakah dengan berbagi pengetahuan dalam perencanaan karir mampu meningkatkan efikasi diri dalam membuat keputusan karir seseorang. Melalui eksperimen yang telah dilakukan diketahui bahwa berbagi pengetahuan mampu secara efektif meningkatkan efikasi diri dalam membuat keputusan karir. Metode ini terbukti relevan dengan penelitian sebelumnya yang menyatakan bahwa berbagi pengetahuan mampu meningkatkan pengalaman pembelajaran seseorang (Alajmi, 2008). Ketika pengetahuan sendiri ditambahkan ke dalam pengetahuan yang dibagi oleh orang lain, maka solusi yang didapatkan akan menjadi lebih cepat dan efisien
(Denning, 2004). Peneliti memfasilitasi berbagi pengetahuan dalam kelompok dengan tujuan agar peserta dapat saling meningkatkan keyakinannya untuk membuat keputusan karir (Wang, Zhang \& Shao, 2010). Selain itu, peningkatan tersebut juga didukung dengan adanya pengkondisian pengetahuan yang dibagi dalam kelompok sehingga hanya informasi, ide, saran dan keahlian yang relevan saja yang dibagi saat peserta dalam kelompok (Bartol \& Srivastava, 2002).

Pemilihan subjek penelitian ternyata juga memiliki dampak dalam peningkatan efikasi diri subjek. Penelitian Isik (2010) menyebutkan bahwa subjek dengan umur 21 tahun keatas terbukti lebih tinggi skor CDSE-nya dibandingkan kelompok umur yang lebih muda. Selain itu hasil penelitian tersebut juga menyebutkan bahwa subjek mengalami kesulitan dalam mengerjakan tugas-tugas di subskala pemecahan masalah. Meningkatnya efikasi diri dalam membuat keputusan karir ini juga tidak lepas dari ketersediaan empat sumber efikasi diri (Bandura, 1997) yang dihadirkan dalam kegiatan ini. Empat sumber efikasi tersebut mampu terfasilitasi dalam kelompok yang dibuat 
oleh peneliti. Efikasi diri dapat disebabkan atas kombinasi keempatnya ataupun karena masing-masing sumber. Sesuai dengan konsep Bandura bahwa sebuah konsekuensi atas sebuah perilaku dapat dipelajari dengan melakukan pengamatan di luar dirinya sehingga seseorang tidak perlu belajar dari pengalaman sendiri untuk mengetahui berbagai konsekuensi atas sebuah perilaku. Hal ini disebut juga sebagai modelling. Sejalan dengan Bandura, Amstrong (2008) menyatakan bahwa modelling dapat membantu seseorang untuk meningkatkan pengetahuan, ketrampilan serta pengadopsian perilaku tertentu namun efektivitasnya tergantung bagaimana karakteristik dan konsekuensi tindakan model dalam menghadapi stimulus tertentu. Individu dapat belajar dari model dengan mengamati orang lain yang memiliki karakteristik yang sama dengan dirinya dan dapat belajar dari pengalaman orang tersebut untuk meningkatkan efikasi diri.

Peneliti menyediakan media sharing dari role model pada hari pertama untuk memfasilitasi modelling dari orang yang berkarir diperusahaan ataupun yang berkarir sebagai usahawan. Selain sharing secara langsung, peneliti juga memberikan berbagai video yang relevan dengan keberhasilan berkarir seseorang. Video yang ditayangkan banyak mengungkap pentingnya menetapkan karir, pengembangan jaringan dan informasi serta pemecahan masalah secara efektif dan inovatif. Selain sharing dari role model, hari pertama merupakan pengkondisian awal untuk meningkatkan pengetahuan peserta tentang cara berbagi pengetahuan yang efektif. Selain itu, peserta didorong untuk memunculkan rasa percaya antar sesama peserta terutama sesama anggota kelompok. Selain menfasilitasi modelling, intervensi ini juga memberikan ruang untuk peserta agar dapat belajar dari keberhasilannya masing-masing untuk membuat perencanaan karir. Setiap sesi merupakan tahapan yang saling berkaitan dan di dalamnya selalu berisikan tugas-tugas yang harus dikerjakan karena berpengaruh pada keberhasilan perencanaan karir peserta.

Hari kedua adalah sesi Creative Problem Solver and Self Mastery. Peserta diajarkan dan saling berbagi tips untuk membuat pemecahan masalah secara kreatif sebagai bekal membuat perencanaan karir dan mengatasi berbagai hambatan yang seringkali muncul selama mengejar karir impian. Selain itu, peserta diminta mengevaluasi diri dan mengidentifikasi keahlian, sifat, minat dan nilai-nilai diri yang dimiliki untuk mencapai karir yang dinginkan. Keberhasilan peserta dalam penugasan dan melakukan penilaian diri memberikan kontribusi dalam peningkatan efikasi diri peserta terutama ketika mereka saling berbagi tentang solusi yang 
tepat untuk mengembangkan diri setelah mengetahui kelemahan masing-masing.

Hari ketiga adalah sesi The Power of Information yang memberi ruang pada peserta untuk seluas-luasnya mencari informasi dengan menggunakan media internet. Pada sesi ini peserta benar-benar secara nyata diminta untuk saling berbagi informasi kepada peserta lain. Informasi apapun asalkan relevan untuk menunjang karir dituliskan dalam lembar yang telah tersedia. Tujuan sesi ini adalah memfasilitasi peserta untuk mengumpulkan dan membagi informasi karir secara efektif.

Sesi terakhir berupa materi The Ultimate Goal for The Ultimate Career and Future Career Plans. Materi ini dimaksudkan untuk menanamkan pemahaman kepada peserta akan pentingnya membuat tujuan yang efektif dan membekali mereka dengan metode terbaik untuk membuat tujuan. Materi lain dalam sesi ini disajikan agar peserta dapat menjaga karirnya sesuai dengan jalur yang diharapkan. Tujuan yang jelas hasil umpan balik yang membangun dari peserta lain akan membuat peserta semakin mantap dalam memutuskan karirnya karena banyak mendapatkan masukan dan gambaran karir dari orang lain.

Selain belajar dari orang lain dan belajar dari pengalaman sendiri, peneliti juga menyediakan ruang untuk dapat saling mendukung secara positif. Sejak awal pembentukan kelompok, masing- masing kelompok telah dikondisikan untuk saling memberi dukungan sesama anggota dengan memberikan apresiasi positif dan feedback bila dibutuhkan. Apresiasi ini lebih banyak secara verbal yang tentunya dapat meningkatkan efikasi seseorang jika apresiasi verbal ini dalam konteks yang tepat. Ketika dalam sesi Self Mastery peserta diminta untuk menuliskan kekurangan dan kelebihan masingmasing dan khusus bagi kekurangan yang dimiliki dibahas dan dicari solusinya secara bersama-sama. Selain itu, peneliti juga menempatkan fasilitator agar dapat mengarahkan peserta untuk dapat secara aktif saling berbagi pengetahuan dan saling memberikan support yang positif dalam proses tersebut. Fasilitator juga diminta untuk secara personal memberikan motivasi bila dinilai ada peserta yang merasa kesulitan ataupun kurang aktif selama kegiatan berlangsung sehingga dapat menurunkan emosi-emosi negatif yang menghambat proses berbagi pengetahuan dan perencanaan karir masingmasing peserta.

Sumber-sumber efikasi di atas secara aktual telah dapat diimplementasikan dalam kegiatan berbagi pengetahuan. Hal ini dapat dipahami karena setiap partisipan memiliki ketertarikan yang sama, rasa kepedulian untuk saling berbagi ilmu dan saling berusaha memperdalam pengetahuan (Wenger, McDermot, \& Snyder, 2002) terkait karir impiannya. Selama proses 
intervensi peserta juga dituntut untuk selalu berinteraksi secara aktif dalam kelompok. Hal ini dilakukan agar setiap orang memiliki peran yang penuh dalam upaya berbagi pengetahuan sehingga akan mempercepat pembelajaran masingmasing peserta (Lesser \& Storck, 2001).

Berdasarkan perhitungan statistik, penelitian ini terbukti secara signifikan mampu meningkatkan efikasi diri dalam membuat keputusan karir dengan sumbangan efektif sebesar $38.8 \%$. Peningkatan ini sayangnya belum mampu mengubah rata-rata kategori peserta (Mean $83,63)$ dari kategori sedang dengan range skor 79 - 102 ke kategori tinggi dengan range 103 - 110. Hasil penjumlahan ratarata perolehan skor dengan efek intervensi adalah 95,43 (sedang). Peneliti menyadari bahwa implementasi kegiatan berbagi pengetahuan memang sebuah tantangan yang sulit bahkan bagi organisasi yang telah mapan (Szulanski, 1996; Argote et al, 2000; Bakker dkk, 2006). Salah satu hal yang krusial adalah bagaimana menciptakan rasa percaya untuk membagi pengetahuan miliknya kepada orang lain sehingga tercipta iklim kelompok yang kondusif.

Peneliti menyadari beberapa keterbatasan penelitian yang memengaruhi perubahan efikasi diri peserta intervensi misalnya durasi intervensi yang belum tepat karena berdasarkan hasil evaluasi pada sesi 1 dan sesi 3 para peserta terlihat kesulitan mengerjakan tugas-tugasnya. Hal ini mengindikasikan bahwa untuk sesi 1 dan 3 perlu dialokasikan waktu yang lebih banyak sehingga peserta memiliki waktu yang cukup untuk memahami dan mempraktekkan hal-hal yang telah dipelajari sehingga mampu meningkatkan efek dari intervensi ini. Hal lainnya adalah terkait dengan faktor lingkungan atau tempat kegiatan yang belum mampu peneliti kontrol. Suasana kafe yang terbuka dan dekat dengan jalan raya memungkinkan terjadinya kehilangan konsentrasi pada kegiatan. Usaha untuk meningkatkan efektivitas intervensi ini dapat dilakukan dengan melakukan penyesuaian waktu dan dengan menyediakan lingkungan yang kondusif. Suasana yang kondusif sangat penting dan hal ini telah disadari oleh peneliti sebelumnya (Choi, Kang \& Lee, 2008; Lee, Gillespie, Mann \& Wearing, 2010). Lingkungan yang terkondisi disertai dengan munculnya rasa percaya antar anggotanya akan mampu mengurangi rasa canggung dan membuat peserta termotivasi untuk membagi pengetahuan. Pada hari pertama intervensi para peserta masih cenderung pasif namun pada sesi-sesi berikutnya sudah menunjukkan peningkatan keaktifan dalam berbagi pengetahuan. Pengkondisian dalam kelompok secara intens dilakukan oleh fasilitator masing-masing kelompok sehingga ketika dalam kelompok para peserta mulai nyaman untuk saling berba- 
gi pengetahuan dan secara aktif mengerjakan tugas-tugas selama kegiatan berlangsung. Usaha untuk menyediakan situasi yang kondusif ini sudah dilakukan oleh peneliti pada keseluruhan proses intervensi namun masih dapat dioptimalkan kembali untuk mendapatkan hasil yang lebih baik.

\section{SIMPULAN DAN SARAN}

\section{Simpulan}

Perencanaan karir dengan menggunakan metode berbagi pengetahuan terbukti secara signifikan mampu meningkatkan efikasi diri dalam membuat keputusan karir para pencari kerja yang berdampak pada munculnya respon perilaku yang lebih positif terhadap tugas-tugas terkait karir pilihannya. Efektivitas berbagi pengetahuan masih dapat ditingkatkan kembali dengan memastikan tersedianya informasi yang relevan untuk dibagi, role model yang tepat, serta adanya kelompok yang relatif homogen, memiliki ketertarikan yang tinggi terhadap topik bahasan dan menunjukkan sikap saling percaya.

\section{Saran}

Program perencanaan karir terbukti mampu meningkatkan efikasi diri dalam membuat keputusan karir sehingga kegiatan sejenis dapat diimplementasikan kepada para pencari kerja sebelum mereka memutuskan untuk melamar sebuah pekerjaan. Metode yang digunakan dapat dikombinasikan dengan metode lain sehingga didapatkan metode yang paling efektif.

Langkah yang dapat ditempuh adalah dengan membuat forum mingguan atau bulanan untuk para anggotanya. Selain memfasilitasi forum berbagi pengetahuan, lembaga karir juga dapat membuat Career Coaching and Counseling untuk memonitor perkembangan anggotanya. Instrumen yang dapat digunakan adalah Buku Follow Up semacam buku diary yang dapat digunakan oleh Coach dan Counselor sebagai acuan intervensi. Buku ini berfungsi seperti Log Book di pabrikpabrik atau Medical Record dalam dunia kesehatan.

Kontribusi yang dapat diberikan oleh pihak universitas untuk menunjang karir para lulusannya adalah dengan menyediakan kegiatan sejenis. Penelitian di Bahamas oleh Rowland (2004) menguatkan saran ini karena menurut penelitian tersebut dengan mendatangi kantor karir kampus dapat memunculkan kepuasan kerja dan membuat seseorang mampu mengambil keputusan karir. Kegiatan berbagi pengetahuan ini akan lebih efektif jika dilakukan sebelum mahasiswa lulus karena kelompok yang dibuat akan lebih homogen dengan keunggulan lain seperti unsur kedekatan para peserta sehingga 
akan lebih mudah memunculkan rasa percaya antar anggota kelompok.

Bagi peneliti selanjutnya yang ingin melakukan penelitian sejenis dapat lebih fokus pada bagaimana menyediakan tempat yang lebih terkontrol sehingga rasa percaya untuk berbagi pengetahuan lebih dapat dikendalikan. Selain tempat yang lebih kondusif, dalam seleksi subjek perlu juga mempertimbangkan faktorfaktor lain seperti tingkat pemahaman subjek dan kemampuan berkomunikasi subjek. Hal ini dilakukan untuk memperlancar proses berbagi pengetahuan sehingga tercipta kondisi kelompok yang lebih dinamis dan tidak terpusat pada orang-orang tertentu saja. Selain itu untuk menjaga konsistensi peningkatan efikasi diri para peserta maka perlu dibuat kurikulum lanjutan dari intervensi ini sehingga peserta akan lebih terbantu untuk mengembangkan karir yang diinginkan.

\section{DAFTAR PUSTAKA}

Amstrong, N. (2008). Role modelling in the clinical workplace. British Journal of Midwifery, 16(9), 596603.

Badan Pusat Statistik. (2011). Pengangguran terbuka menurut pendidikan tertinggi yang ditamatkan, 20042011. Diunduh dari http://www. bps.go.id/tab_sub/view.php?tabel = 1\&daftar $=1 \&$ id_subyek $=06 \&$ notab $=4$

Ballout, H. I. (2009) Career commitment and career success: Moderating role of self-efficacy. Career Development International, 14(7), 655-670. doi:10.1108/13620430911005708

Bandura, A. (1997). Self-efficacy: The exercise of control. New York: Freeman.

Bartol, K. M., \& Srivastava, A. (2002). Encouraging knowledge sharing: The role of organizational reward systems. Journal of Leadership and Organization Studies, 9(1), 64-76.

Betz, N. E., Hammond, M. S., \& Multon, K. D. (2005). Reliability and validity of five-level response continua for the career decision self-efficacy scale. Journal of Career Assessment. 13(2),131-149.doi:10.1177/ 1069072704273123

Buckley, S., \& Giannakopoulos, A. (2011). Sharing knowledge: The CoP way. Dalam K. Grant (Eds), ICIME 2011 2nd International Conference on Information Management and Evaluation. Toronto, Canada: Ryerson University.

Choi, S.Y., Kang, Y.S., \& Lee, H. (2008). The effects of socio-technical 
enablers on knowledge sharing: an exploratory examination. Journal of Information Science, 34 (5), 742754. doi: 10.1177/016555150708 7710

Crites, J. O. (1978). Career maturity inventory: Theory \& research handbook (2nd ed.). Monterey, CA: California Test Bureau/McGraw Hill.

Denning, S. (2004, September). Knowledge sharing at the world bank. Naskah dipresentasikan pada International Conference on Nuclear Knowledge Management Strategies, Information Management and Human Resource Development, Saclay, Perancis. Diunduh dari http://www.iaea.org/km/cnkm/ papers/denningusa.pdf

Fouad, N., Cotter, E. W., \& Kantamneni, N. (2009). The effectiveness of a career decision-making course. Journal of Career Assessment, 17(3), 338-347.

Garcia, P. R. J. M., Restubog, S. L. D. , Toledano, L. S., Tolentino, L. R., \& Rafferty, A. E. (2011). Differential moderating effects of student- and parent-rated support in the relationship between learning goal orientation and career decision- making self-efficacy. Journal of Career Assessment.

George, R. L., \& Cristiani, T. S. (1990). Counseling theory and practice $\left(3^{\text {rd }}\right.$ Ed.). Boston : Allyn and Bacon.

Greenbank, P., \& Hepworth, S. (2008a). Improving the career decisionmaking behaviour of working class students: Do economic barriers stand in the way? Journal of European Industrial Training, 32(7), 492-509.

Greenbank, P., \& Hepworth, S. (2008b). Working class students and the career decision making process: a qualitative study. Diunduh dari Higher Education Careers Service Unit (HECSU), Manchester website: http://www.hecsu.ac.uk/ working_class_students_and_the_ca reer_decision_making_process.htm

Işık, E. (2010). Career decision selfefficacy among Turkish undergraduate students. Electronic Journal of Research in Educational Psychology, 8(2), 749-762.

Jeon, S., Kim, Y.G., \& Koh, J. (2001). An integrative model for knowledge sharing in communities-of-practice. Journal of Knowledge 
Management,15(2), $\quad$ 251-269. doi:10.1108/13673271111119682

King, W. R. (2006). Knowledge sharing. Dalam D. G. Schwartz (Eds.), Encyclopedia of knowledge management (pp. 493-498). London: Idea Group.

Koivisto, P., Vinokur, A. D., \& Vuori, J. (2011). Effects of career choice intervention on components career preparation.The Career Development Quarterly,59, 345-366.

Krapp, K. (2005). Psychologists and their theories for students. USA: Thomson Gale.

Krathwohl, D. R. (2002). A revision of Bloom's taxonomy: An overview. Theory Into Practice, 41(4), 212218.

Lave, J., \& Wenger, E. (1991). Situated learning: Legitimate peripheral participation. Cambridge: Cambridge University Press.

Lee, P., Gillespie, N., Mann, L., \& Wearing, A. (2010). Leadership and trust: Their effect on knowledge sharing and team performance. Management Learning, 41(4), 473491. doi:10.1177/1350507610362 036
Lesser,E. L., \& Storck, J. (2001). Communities of practice and organizational performance. IBM Systems Journal, 40, 831-41.

Lunenburg, F. C. (2011). Self-efficacy in the workplace: Implications for motivation and performance. International Journal of Manage ment, Business, and Administration, 14, 1- 6 .

Mulyana, O. P. (2009). Peningkatan efikasi diri terhadap pengambilan keputusan karir melalui pelatihan perencanaan karir (Tesis tidak diterbitkan). Universitas Gadjah Mada,Yogyakarta, Indonesia.

Nam, S. K., Yang, E., Lee, S. M., Lee, S. E., \& Seol, H., (2010). A psychometric evaluation of the career decision self-efficacy scale with korean students: A rasch model approach. Journal of Career Assessment, 38(2), 147-166. doi:10.1177/0894845310371374

Nawaz, S., \& Gilani, N. (2011). Relationship of parental and peer attachment bonds with career decision-making self-efficacy among adolescents and post-adolescents. Journal of Behavioural Sciences, 21(1). 33-47. 
O'Brien, K. M., Bikos, L. H., Epstein, K. L., Flores, L. S., Dukstein, R. D. \& Kamatuka, N. A. (2000). Enhancing the career decision-making selfefficacy of upward bound students. Journal of Career Development, 26. doi:10.1177/08948453000260040 4

Preston, A. P., \& Biddle, G. (1994). "To be or not to be?": Making a professional career choice.The International Journal of Career Management, 6(1), 28-32.

Reese, R. J., \& Miller, C. D. (2006). Effects of a university career development course on career decision-making self-efficacy. Journal of Career Assessment, 14, 252-266.

Retna, K. S., \& Ng, P. T.(2010), Communities of practice: Dynamics and success factors, Leadership \& Organization Development Journal, 32, 41-59. doi:10.1108/014377311 11099274

Scott, A. B., \& Ciani, K.D. (2008). Effects of an undergraduate career class on men's and women's career decision making self efficacy and vocational identity. Journal of Career Development, 34(3), 263-285.
Shadish, W. R., Cook, T. D., \& Campbell, D. T. (2010). Experimental and quasi-experimental designs for generalized causal inference. Boston: Houghton Mufflin and Company.

Suppiah, V., \& Sandhu, M.S. (2011). Organisational culture's influence on tacit knowledge-sharing behaviour. Journal of Knowledge Management, 15(3), 462-477. doi:10.1108/13673271111137439

Suryadarma, D., Suryahadi, A., \& Sumarto, S. (2007). Reducing unemployment in indonesia:results from a growth-employment elasticity model. Diunduh dari East Asian Bureau of Economic Research (EABER) website: Error! Hyperlink reference not valid.

Tansley, D. P., Jome, L. M., Haase, R. F., \& Martens, M. P. (2007). The effect of message framing on college student's career decision making. Journal of Career Assessment, 15, 301-316.

Taylor, K. M., \& Betz, N. E. (1983). Applications of self-efficacy theory to the understanding and treatment of career indecision. Journal of Vocational Behavior, 22, 63-81. 
Wang, J., Zhang,D., \& Shao, J. (2010) Wenger, E., McDermott, R., \& Snyder, V. Group training on the improvement M. (2002). Cultivating communities of college student's career decisionmaking self-efficacy. Health, 2(6), 551-556. doi:10.4236/health.2010. of practice: A guide to managing knowledge. Boston: Harvard Business School. 26082 